\title{
WEED TECHNOLOGY
}

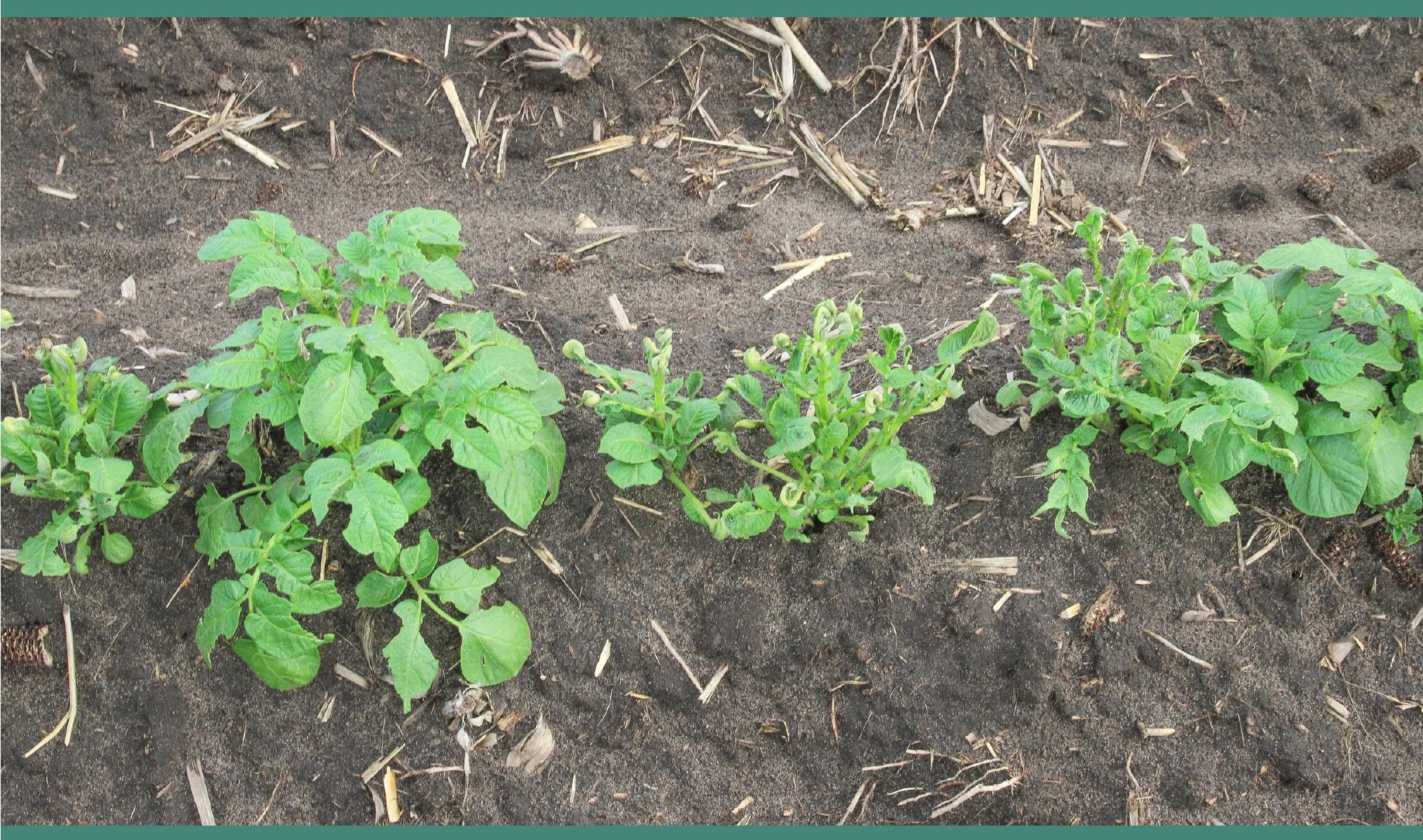




\section{Published six times a year by the Weed Science Society of America}

Jason K. Norsworthy, Editor

The Weed Science Society of America publishes original research and scholarship in the form of peer-reviewed articles in three international journals. Weed Science is focused on understanding "why" phenomena occur in agricultural crops. As such, it focuses on fundamental research directly related to all aspects of weed science in agricultural systems. Weed Technology focuses on understanding "how" weeds are managed. As such, it is focused on more applied aspects concerning the management of weeds in agricultural systems. Invasive Plant Science and Management is a broad-based journal that focuses not only on fundamental and applied research on invasive plant biology, ecology, management, and restoration of invaded non-crop areas, but also on the many other aspects relevant to invasive species, including educational activities, policy issues, and case study reports. Topics for Weed Technology include all aspects of weed management in agricultural, horticultural, ornamental, forestry, aquatic, turf, recreational, rights-of-ways, and other settings; weed resistance to herbicides; herbicide resistant crops; biological weed control agents; new weed management techniques; impacts of weed competition with crops; vegetation management with plant growth regulators; weed surveys; weed-related grower surveys; education; and extension. Symposia papers and reviews are accepted. Consult the editor for additional information.

\section{Associate Editors (Assignment Year)}

Jason Bond, Stoneville, MS (2010)

Kevin Bradley, Columbia, MO (2012)

Barry Brecke, Jay, FL (2013)

Peter Dittmar, Gainesville, FL (2016)

Steve Fennimore, Salinas, CA (2004)

Aaron Hager, Urbana, IL (2012)
Brad Hanson, Davis, CA (2013)

Prashant Jha, Huntley, MT (2016)

Amit Jhala, Lincoln, NE (2018)

William Johnson, West Lafayette, IN (2007)

Andrew Kniss, Laramie, WY (2016)

Drew Lyon, Pullman, WA (2018)

Patrick McCullough, Griffin, GA (2016)

Scott McElroy, Auburn, AL (2012)
Robert Nurse, Guelph, ON (2016)

Darren Robinson, Ridgetown, ON (2008)

Larry Steckel, Jackson, TN (2007)

Daniel Stephenson, Alexandria, LA (2013)

Mark VanGessel, Georgetown, DE (2013)

Michael Walsh, Crawley, Australia (2016)

Eric Webster, Baton Rouge, LA (2018)

Cammy Willett, Fayetteville, AR (2017)

Tracy Candelaria, Managing Editor

\section{Officers of the Weed Science Society of America}

http://wssa.net/society/bod/

Weed Technology (ISSN 0890-037X) is published by the Weed Science Society of America, 12011 Tejon Street, Suite 700, Westminster, CO 80234. It is published bimonthly, one volume per year, six issues per year beginning in February.

Membership includes online access to Weed Technology, Weed Science, Invasive Plant Science and Management, and the online WSSA Newsletter. Dues should be sent to WSSA, 12011 Tejon Street, Suite 700, Westminster, CO 80234 no later than December 1 of each year. Membership in the society is on a calendar-year basis only.

New subscriptions and renewals begin with the first issue of the current volume. Please visit the Weed Technology subscription page at https://www.cambridge.org/core/journals/weed-technology/subscribe; Email: subscriptions_newyork@cambridge.org in USA, journals@cambridge.org outside USA.

Weed Technology publishes six times a year in February, April, June, August, October, and December. Annual institutional electronic subscription rates: US \$388.00; UK £270.00.

Please use Editorial Manager to access manuscript submissions (http://www.editorialmanager.com/wt). Authors are asked to pay $\$ 85$ for the first page and $\$ 65$ per page thereafter as a portion of the cost of publication, plus an additional processing charge of $\$ 55$ per manuscript if none of the authors are WSSA members. The Editor can make exceptions in advance when justified.

The Weed Science Society of America fully subscribes to the belief that progress in science depends upon the sharing of ideas, information, and materials among qualified investigators. Authors of papers published in Weed Technology are therefore encouraged, whenever practicable and when state and federal laws permit, to share genotypically unique propagative materials they might possess with other workers in that area who request such materials for the purpose of scientific research.

Weed Technology published by the Weed Science Society of America.

Copyright 2019 by the Weed Science Society of America.

All rights reserved. Reproduction in part or whole prohibited.

\section{Cover}

Auxin symptomology on potato seedlings originating from daughter seed tubers taken from mother plants treated with dicamba at $20 \mathrm{~g} \mathrm{ha}^{-1}$. Notice the varied response among plants where some exhibit symptoms and others are less symptomatic. Photo credit: Andy Robinson. 


\section{- RESEARCH ARTICLES}

Effect of Growth Stage on Cotton Response to a Sublethal Concentration of Dicamba. John T. Buol, Daniel B. Reynolds, Darrin M. Dodds, J. Anthony Mills, Robert L. Nichols, Jason A. Bond, Johnie N. Jenkins and Janice L. DuBien

Response of 'Russet Burbank' Seed Tubers Containing Dicamba and Glyphosate. Nelson D. Geary, Harlene Hatterman-Valenti, Gary A. Secor, Richard K. Zollinger and Andrew P. Robinson . . . . . . . . . . . . 9 Effect of Low Doses of Dicamba Alone and in Combination with Glyphosate on Parent Soybean and Offspring. Gordon T. Jones, Jason K. Norsworthy, Tom Barber, Edward Gbur and Greg R. Kruger . . . . . . . . . . . . . . . . 17 Off-Target Movement of Diglycolamine Dicamba to Non-dicamba Soybean Using Practices to Minimize Primary Drift. Gordon T. Jones, Jason K. Norsworthy and Tom Barber . . . . . . . . . . . . . . . . . . . . . 24 Response of Soybean Offspring to a Dicamba Drift Event the Previous Year. Gordon T. Jones,

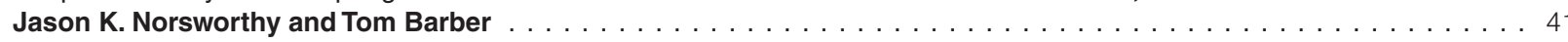
Off-target Movement of DGA and BAPMA Dicamba to Sensitive Soybean. Gordon T. Jones, Jason K. Norsworthy, Tom Barber, Edward Gbur and Greg R. Kruger . . . . . . . . . . . . . . . . . . Droplet Size Impact on Efficacy of a Dicamba-plus-Glyphosate Mixture. Thomas R. Butts, Chase A. Samples, Lucas X. Franca, Darrin M. Dodds, Daniel B. Reynolds, Jason W. Adams, Richard K. Zollinger, Kirk A. Howatt, Bradley K. Fritz, W. Clint Hoffmann, Joe D. Luck and Greg R. Kruger .

Evaluating risks of plant growth regulator-resistant soybean technologies to horseradish production.

Kayla N. Wiedau, Ronald F. Krausz, S. Alan Walters, Joseph L. Matthews and Karla L. Gage . . . . . . . . . . . . 75

Effects of Low-Dose Flumioxazin and Metribuzin Postemergence Applications on Soybean. Daniel O. Stephenson IV,

Todd A. Spivey, Michael A. Deliberto Jr., David C. Blouin, Brandi C. Woolam and Trace B. Buck. . . . . . . . . . . . . 87

Palmer Amaranth (Amaranthus palmeri) and Velvetleaf (Abutilon theophrasti) Control in No-Tillage Conventional (Non-genetically engineered) Soybean Using Overlapping Residual Herbicide Programs. Debalin Sarangi

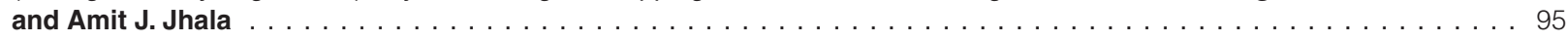

Herbicide Options for Control of Palmer Amaranth (Amaranthus palmeri) and Common Waterhemp

(Amaranthus rudis) in Double-Crop Soybean. Marshall M. Hay, Douglas E. Shoup and Dallas E. Peterson . . . . . . . . . 106

Control of Atrazine-Resistant Palmer Amaranth (Amaranthus palmeri) in Double-Crop Grain Sorghum. Marshall M. Hay,

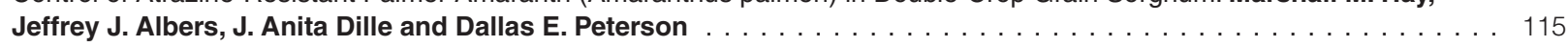
Turnip Tolerance to Preplant Incorporated Trifluralin. Sushila Chaudhari, Katherine M. Jennings, Stanley Culpepper,

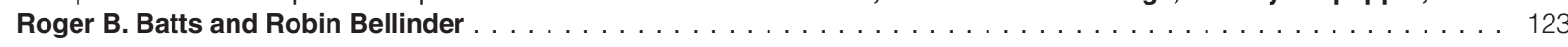
Response of Palmer Amaranth and Sweetpotato to Flumioxazin/Pyroxasulfone. Shawn C. Beam, Sushila Chaudhari, Katherine M. Jennings, David W. Monks, Stephen L. Meyers, Jonathan R. Schultheis, Mathew Waldschmidt and

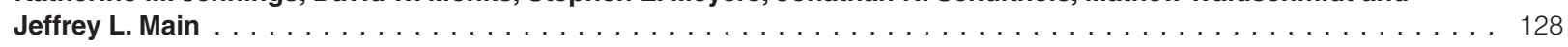

Evaluation of POST-Directed Applications of Flumioxazin in New Mexico Chile Pepper. Brian J. Schutte, Erik A. Lehnhoff

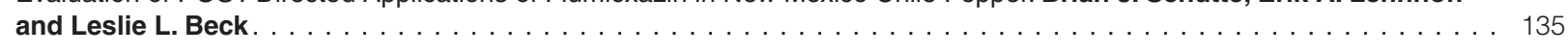
Development and Evaluation of a Hole-Punch Applicator for Precision Application of Preemergence Herbicides in Plasticulture Production. Nathan S. Boyd and Arnold Schumann . . . . . . . . . . . . . . . . . 142 Tolerance of Sweetpotato to Herbicides Applied in Plant Propagation Beds. Stephen C. Smith, Katherine M. Jennings, David W. Monks, Jonathan R. Schultheis and S. Chris Reberg-Horton Droplet-Size Effects on Control of Chloris spp. with Six POST Herbicides. J. Connor Ferguson, Bhagirath S. Chauhan, Rodolfo G. Chechetto, Andrew J. Hewitt, Steve W. Adkins,

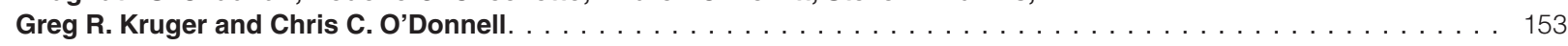
Can Weeds Overtopping Soybean or Adzuki Bean Be Mechanically Pulled to Reduce Their Seed Input? Marie-Josée Simard, Eric R. Page and Robert E. Nurse . Preplant and Residual Herbicide Application Timings for Weed Control in No-Till Soybean. Kurt M. Vollmer, Mark J. VanGessel, Quintin R. Johnson and Barbara A. Scott 
Suppression of Annual Ryegrass in Corn with Nicosulfuron. Taïga B. Cholette, Nader Soltani, David C. Hooker,

Darren E. Robinson and Peter H. Sikkema . .

Sensitivity of Dry Bean to Herbicides Applied Preplant for Glyphosate-Resistant Horseweed Control in a

Strip-Tillage Cropping System. Nader Soltani, Christy Shropshire and Peter H. Sikkema .

Fineleaf Fescue Species and Variety Tolerance to Glyphosate. Shawn D. Askew, Whitnee B. Askew

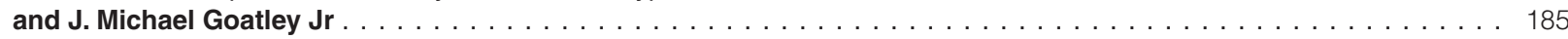

Great Plains Yucca (Yucca glauca) Control on Shortgrass Rangelands. Walter H. Fick and Keith Harmoney . . . . . . . . 192

Key Morphological Events following Late-Season Goosegrass (Eleusine indica) Germination.

Robert Andrew Kerr, Lambert B. McCarty, William C. Bridges and Matthew Cutulle. .

\section{- WEED BIOLOGY AND COMPETITION}

Studies on Seed biology, Distribution, and Chemical Control of Smellmelon (Cucumis melo var. agrestis Naudin):

An Invasive Weed. Reza Noor-Ziarat, Mohammad Rezvani, Naser Bagherani and W. James Grichar . .

\section{- RESEARCH ARTICLES}

Carolina Redroot (Lachnanthes caroliniana) in Cranberry: Assessment of Shoot and Rhizome Control with POST Herbicides. Thierry E. Besançon.

Dispersal and Frequency of Glyphosate-Resistant and Glyphosate-Tolerant Weeds in Soybean-producing Edaphoclimatic Microregions in Brazil. Felipe Ridolfo Lucio, Augusto Kalsing, Fernando Storniolo Adegas,

Caio Vitagliano Santi Rossi, Núbia Maria Correia, Dionisio Luiz Pisa Gazziero and Alexandre Ferreira da Silva. 